\title{
FLORISTIC DISTRIBUTION ACCORDING TO THE EDAPHIC PARAMETERS OF A STEPPE ZONE, CASE OF STUDY: THE NATURE RESERVE “EL-MERGUEB” M'SILA, ALGERIA
}

\author{
AMINA ADJABI ${ }^{1 \star}$, HACHEMI SIDI $^{1}$, RABAH BOUNAR $^{2}$, HAMID REZA NASERI $^{3}$ \\ ${ }^{1}$ Laboratory of Research in Ecology and Environment (LREE), University Abdurrahman Mira of Bejaia, Bejaia, \\ Algeria; e-mail: adjabi_amina@yahoo.com, shaokas@yahoo.fr \\ ${ }^{2}$ Department of Natural and Life Sciences, University Mohamed Boudiaf of M'sila, M’sila, Alegria; e-mail: rabah. \\ bounar@univ-msila.dz \\ ${ }^{3}$ International Desert Research Center (IDRC) University of Tehran, Tehran, Islamic Republic of Iran; e-mail: hrnaseri@ut.ac.ir
}

*Author for correspondence

\begin{abstract}
Adjabi A., Sidi H., Bounar R., Naseri H.R.: Floristic distribution according to the edaphic parameters of a steppe zone, case of study: the Nature Reserve "El-Mergueb” M'sila, Algeria. Ekológia (Bratislava), Vol. 38, No. 4, p. 336-352, 2019.

The natural site of El-Mergueb, is one of the specific steppe ecosystem, that occupies an area of 16,481 ha; it is among the particular ecosystems in Algeria and is unique in northern Africa. It is located in the geographical limit of the Tell Atlas and the Saharan Atlas. It is at an altitude of 550 to $800 \mathrm{~m}$, with a typically arid climate. The faunistic and floristic richness, quite specifically, contains species protected and classified in the IUCN: Chlamydotis and Gazella, as well as an autochthonous plant diversity: Stipa, Pistacia and Ziziphus. This study is based on the analysis of the vegetation by characterizing the associated soil type through the monitoring of the Eco-pedological relation during two seasons in three years: 2015-2016-2017. Nine soil profiles with a collection of twenty-one samples for each station of experimentation were collected. The results thus obtained showed that the content of the parameters analyzed is between low and average of the three stations. The average of the floristic analysis of the study area made it possible to define 34 botanical families spread over 69 botanical genus and 275 species. The analysis and the description of a natural space is important to establish a typology which is that is the basis for the development of management plans to conserve this category of protected areas. The FAC (Factorial Analysis of Correspondence) is relative to the individualization and the typology for three sequences, which corresponds to the groups (A), (B) and $(\mathrm{C})$ also for the places in arid climate variants with very cold winters.
\end{abstract}

Key words: protected areas, steppe soils, anthropic pressure, arid climate, steppe vegetation.

\section{Introduction}

Climate change is anticipated to have far reaching effects on the sustainable development of developing countries, including their ability to attain the United Nations Millennium 
Development Goals by 2015 (United Nations Framework Convention on Climate Change, 2007). In recent years, climate change caused dramatic shifts in species' distributions and extinctions, particularly across fragmented or vulnerable ecosystems (Hilbert et al., 2007). The need to protect diverse biological resources from the ongoing development pressures is one of today's most pressing environmental challenges. In response, "ecosystem services" has emerged as a conservation framework that links human economies and natural systems through the benefits that people receive from nature (Stephen, 2015). Natural or biological diversity on earth is an important prerequisite for humans to exist, as it provides valuable ecosystem services. Changes of biodiversity affect ecosystem functions and services, and consequently, human well-being in urban areas. This is an example of a cycle of socio-ecological interactions within global environmental change, significantly intensified over the last few decades (Breuste et al., 2013). However, there are many threats to biodiversity, including loss of habitat, overexploitation, pollution, alien species and climate change. In order to reduce the rate of biodiversity loss significantly the Convention on Biological Diversity was adopted at the Rio Conference 1992, forming the core of the international Regime on global biodiversity (Wetang'ula, 2009).

Biodiversity loss and the erosion of the capacity of ecosystems to deliver services often respond in similar ways to shared drivers; however, the relationship between them is not simple, and may be different for the various dimensions of biodiversity. For example, the links between local species extinctions and reduced capacity to deliver ecosystem services remain, in many cases, elusive (Leadley et al., 2010). The Convection on Biological Diversity (CBD) defines biodiversity as "the variability among living organisms from all sources including, inter alia, terrestrial, marine and other aquatic ecosystems and the ecological complexes of which they are part; this includes diversity within species, between species and of ecosystems." It is the variety of life on earth at all levels, from genes to worldwide populations of the same species; from communities of species sharing the same small area of habitat to worldwide ecosystems.

Conservation and loss: Biological diversity can be measured in terms of different components (genetic, population/species, and community/ecosystem), and composition refers to the identity and variety of elements in each of the biodiversity components. Structure refers to the physical organization or pattern of the elements. Function refers to ecological and evolutionary processes acting among the elements (Wetangula, 2009). The extent of protected areas (PA) in Africa has been increased over the last few years and currently represents about $5 \%$ of land area. However, the data concerning the extent of protected areas in the region differed from one source to another. According to World Resource Institute, there are 746 protected areas in Africa, covering 1.54 million $\mathrm{km}^{2}$, which is 5.2 per cent of the total land area. Although there has been a rapid increase in the of PAs, which has been observed during the last 10-20 years. Through the region, there tends to be inadequate legislation and ineffective application of the legal measures that do exist, weak institutional support, management that is frequently deficient or even non-existent and inadequate funding are also ubiquitous (Czudek, 2001). Consequently, there is a strong tendency towards "paper parks", whose existence is largely theoretical and not reflected by substantive and durable conservation reserves on the ground (Czudek, 2001). Steppe ecosystems in Algeria cover more than 
20 million ha. The combination of many regressive processes, such as woodcutting, wildfires, overstocking and clearing, have contributed to the present steppe conditions. According to the biogeography, these steppe rangelands belong to the Mediterranean basin, one of the 25 biodiversity hotspots of the globe. Mediterranean ecosystems are considered among the most vulnerable to global change. These ecosystems have evolved under the long history of grazing, and over time, the various farming methods in these areas have shaped the landscapes and resources that are found there. The evaluation of the effect of grazing on plant diversity and structure has been studied extensively in rangeland ecosystems. In more humid environments (productive), grazing is predicted to increase species diversity. Where as, in arid environments grazing can have a negative effect on diversity. In semi-arid Mediterranean grasslands, grazing reduces plant diversity. North African arid grasslands exhibits the same trend where grazing has decreased diversity (Merdas et al., 2017). Mediterranean bioclimates are characterized by winter rains and summer drought (LeHouérou, 2005a,b). In parts of North Africa, a drought occurs when no rain has fallen for at least two years. Perhaps, then, a drought can be defined as a period during which rainfall is insufficient to meet the needs of plants. Droughts meeting this definition have led to the ongoing debates on desertification (Gamoun, 2013).

In this context, this study describes the importance to analyze and investigate the relationship between soil characteristics with plant species inside one of the three municipalities constituting the nature reserve of El- Mergueb, characterized by a typical arid climate, to determine the most important factors affecting the separation of vegetation types. Second aim was to identify the soil characteristics that are an indicator of specific species who characterize this particular ecosystem. Moreover, to have information about the relationship between soil and vegetation of the area of study, it will be possible to apply these results to explain the importance of conserving the biodiversity inside the nature reserves and the rangelands in arid regions; also, for other similar regions exposed to severe arid climate and extensive grazing, to recommend suitable guidance for management and protection of particular and vulnerable arid ecosystem.

\section{Material and methods}

\section{Study area}

The natural site of El-Mergueb is located in the steppe routes of the highlands of Algeria, it extends between the coordinates of Lambert relative to the topographic map of, Ain El-Hadjel to (1/50.000, following: X (608.5 and 626.7) $\mathrm{km}$ and Y (243.6-263.8) km. It straddles three steppe communes on the northern side of the Saharan Atlas belonging to the M'sila province. A protected, area according to the law 83-03 of 5th February 1983 (joradp.dz), relative to the protection of the environment, which elaborates the first legal instrument for the creation of national parks and nature reserves (Kaabeche, 2003) characterized by a potential. The three experimental stations lie between latitudes $\left(35^{\circ} 36^{\prime} 12,6^{\prime \prime} \mathrm{N} \& 35^{\circ} 35^{\prime} 05,7^{\prime \prime} \mathrm{N}\right)$ and longitudes (035'리 $\left.23, \mathrm{E} \& 03^{\circ} 58^{\prime} 08,7^{\prime \prime} \mathrm{E}\right)$ with an altitude of 575 and $634 \mathrm{~m}$ located in the municipality of Ain EL-Hadjel (Fig. 1).

The climate is characterized by hot dry summers and very cold winters; so according to Emberger (1954) and M'sila Weather Station (2017), it has a Saharan superior Mediterranean bioclimate. As per the climatic data of M'sila, a mean minimum temperature of $-0.5^{\circ} \mathrm{C}$ in February and a mean maximum temperature of $46.2^{\circ} \mathrm{C}$ characterize the study area in July, with an annual mean temperature of $19.61{ }^{\circ} \mathrm{C}$, showing very hot summers and very cold winters. The rainfall in the region is erratic and irregular. The average annual rainfall is between (121 and $181 \mathrm{~mm})$, 
which places the study area in an arid bioclimatic variant to very cold winter. Geomorphologically, the study area is a succession of undulations that dominate the relief in the northern part of the reserve forming elongated depressions that converge and concentrate on the surface flows in the form of fine particles, eroded and transported; this zone presents a dominant lithology or limestone where the topographic depressions consist of polygenic quaternary fillings (presence of sandy-sandy facies, marls, limestone, clays and sandy-clayey soils) (Boud-

jaja et al., 2010). Characterized by a high density of flow on the slopes, the main troughs oriented South-WestNorth-East drain areas of spreading of very low slope. The breaks of slopes between the top parts of the reliefs and the foothills are the fissured cliffs with important joints that appear in the landscape feed the slopes in blocks, gravel and pebbles resulting from the collapse of the overhangs (Boudjaja et al., 2010).

\section{Vegetation survey and analysis}

The present study was carried out from March 2015 through February, 2017. Three different stations (with its different habitats), were selected after general survey of the studied area. The phyto-sociological method were used to study vegetation within the selected three locations. A sampling site was selected systematically according to the distribution of species, habitat differences and the vegetation homogeneity, and also the places of soil profiles. Numbers of stands were determined according to different habitats in each station. Present species were recorded and their cover was evaluated visually as a percentage of the ground surface. The vegetation parameters included listing of all species and life forms. Species identification and nomenclature (Maire, 1926, 1928, 1952, 1987), (Quezel, Santa, 1962, 1963). The nomenclature of species adopted is that of the "Med-Cheklist". Plant cover was estimated and the Specimens of each species were collected, identified and supplemented in laboratory of research in Ecology and Environment, University of Bejaia. The chorological types of the various taxa identified were attributed according to the indications of the flora consulted. In the analysis of floristic records, special attention has been paid to endemic and or rare species. It fluctuates between 300 to $400 \mathrm{~m}^{2}$ for forest vegetation and between 5 and $10 \mathrm{~m}^{2}$ in terms of rupicolous vegetation. We have made the floristic list of our three stations (A, B and C). The surveys were carried out during field campaigns during the three years from 2015 to 2017. The floristic surveys were conducted according to subjective sampling in all vegetation types in the study area.

\section{Site description (stations)}

The choice of stations was based on the durability and persistence of the dominant species. As this index showed, this physiognomy revealed three homogeneous and floristically representative and ecological sites: Formation with: Artemisia herba-alba L. (Site A) and formation Salsola vermiculata L. and Anabasis articulata L. (Site B), Artemisia campestris L. and Zizyphus lotus L. (Site C). These species formations were selected to carry out this work. In each of these formations, floristic surveys were carried out respectively 13, 10 and 10 associated with soil profiles (Fig. 2).

- Station A: Artemisia herba-alba L./Ain el Hajal, the geographical coordinates are: $\left(03^{\circ} 56^{\prime} 23,8^{\prime} \mathrm{E}\right.$ $\left.35^{\circ} 36^{\prime} 12,6^{\prime \prime} \mathrm{N}\right)$. the highest point of this facies is $605 \mathrm{~m}$. The Artemisia stands are welcome, with a large aerial 
biomass and a fairly diverse floristic procession. The average height of Artemisia feet does not exceed $70 \mathrm{~cm}$.

- Station B: Salsola vermiculata L. and Anabasis articulata L. (Maader Nahia/Region (Ain eh Hajal). This station is located in the following geographical coordinates: $\left(03^{\circ} 56^{\prime} 29,9^{\prime \prime} \mathrm{E}-35^{\circ} 35^{\prime} 38,6^{\prime \prime} \mathrm{N}\right)$. The vegetation is of average height between 30 and $50 \mathrm{~cm}$ and the floristic procession is rich. The plant cover is quite important.

- Station C: Artemisia campestris L. and Zizyphus lotus L. stands occupy the following geographical coordinates: $\left(03^{\circ} 58^{\prime} 08,7^{\prime \prime} \mathrm{E}-35^{\circ} 35^{\prime} 05,7^{\prime \prime} \mathrm{N}\right)$. This site is located near the forest house (Ain eh Hajal) at $575 \mathrm{~m}$ altitude; the mixed formation in this site is degraded and its height hardly exceeds $30 \mathrm{~cm}$, with a fairly weak floristic procession.

\section{Soil samples and analyses}

The sampling adopted in this study consists of exploiting the main soils that characterize the site of our study. Each type of soil is represented by two and representative profiles of each experimental station. The selection of these profiles was based on the soil map of the region of El-Mergueb. In each profile, the samples were taken on two depths $(0-40$ and $40-60 \mathrm{~cm})$. The choice of these depths is dictated by the fact that they are the parts of the soil where the roots thrive by fixing the plant on its support and feeding to different factors of plant growth: heat, water, all nutrients; it is also where the concept of soil fertility is well connected. Out of a total of (06) to (09), soil samples per station were analyzed, which corresponds to either (21) soil samples in total. The soil profile thus produced is strictly associated with the type of plant formation corresponding to it. Facies with Artemisia herba-alba L., facies with Salsola vermiculata L., Anabasis articulata L. and Artemisia campestris L., Zizyphus lotus L.

The soils were thus collected at each station (A), (B) and (C) in the fields of Ain el Hadjal regions, namely: Mergueb soula (Fenced station): (Station A), Maader Nahia (Station B), side of the forest house (Station C) (Fig. 3).

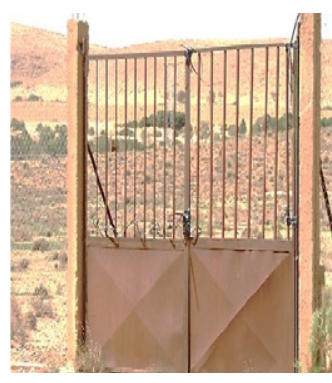

A

Fig. 2. The three experimental station (A), (B) and (C).

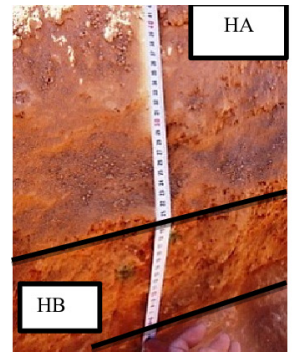

(1) Soil profile A.

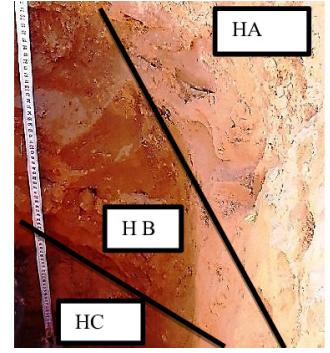

(2) Soil profile B.

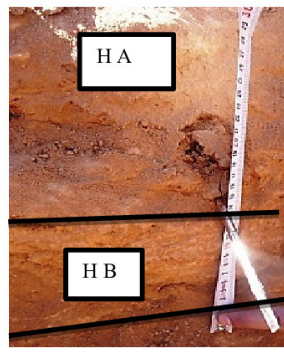

(3) Soil profile C.
Fig. 3. Soil profiles carried out within 3 experimental stations.
The present study deals with the analysis of soil samples from three different sites in El-Mergueb, which were collected in the period 2015-2017 from Ain El Hadjel commune situated towards south east $35^{\circ} 40^{\prime} 26^{\prime \prime}$ nord, $3^{\circ} 52^{\prime} 54^{\prime \prime}$ est of M'sila city. This study was primarily focused on analyzing the physical and chemical parameters from 21 representative sampling and the analytical results were expected to be representative for the entire field. All samples were collected in a plastic bucket. The analysis were carried at the laboratory of research in Ecology and Environment, University Abdurrahman Mira de Bejaia, Algeria.

Samples collected were thoroughly mixed on a piece of clean cloth, 
air dried and the lumps were broken using wooden pestle and mortar (Tandon, 1993). The soil profile thus produced is strictly associated with the type of plant formation corresponding to it. Facies of Artemisia herba-alba L., facies of: Salsola vermiculata L., Anabasis articulata L. and Artemisia campestris L., Zizyphus lotus L. The characterization of each horizon whose objective is to determine the apparent characters of each profile was carried out (color, texture, length, depth, effervescence and the recovery rate) (AFNOR, 1998; Baize, Jabiol, 2011) at the level of each station using the chart of Munsell of color (Pendleton, Nickerson, 1951). The quality of each of the main sand, silt and clay fractions in each soil sample was determined; a $2 \mathrm{~mm}$ sieve was used to separate the present sand by wet sieving through a set of nested sieves. The silt and clay in each sample were determined by the pipette that measured the weight percent of sample method (Robinson, 1922). The $\mathrm{pH}$ values were determined using $\mathrm{pH}$ meter as described by Jackson (1967). For this, $20 \mathrm{~g}$ soil sample was mixed with $40 \mathrm{ml}$ distilled water in 1:2 ratio. The suspension was stirred intermittently with glass rod for 30 minutes and left for one hour. The combine electrode was inserted into supernatant and $\mathrm{pH}$ was recorded. The electrical conductivity of the soil sample was determined on a digital electrical conductivity bridge for which $20 \mathrm{~g}$ soil was added in $40 \mathrm{ml}$ distilled water. The suspension was stirred intermittently for half an hour and kept it for 30 minutes without any disturbances for complete dissolution of soluble salts. The soil was allowed to settle down and then conductivity cell was inserted in the solution to take the reading to record the EC values. The soil organic matter (SOM) was determined by using the modified Walkley-Black method (Chapman, Pratt, 1961). The quantity of organic carbon in the soil was estimated by using the modified WalkeyBlack method (Walkey, 1947) as described by Jackson (1962). $1 \mathrm{~g}$ finely ground dry soil sample was passed through $0.5 \mathrm{~mm}$ sieve without loss and was taken into $500 \mathrm{ml}$ conical flask. To this, $10 \mathrm{ml}$ of $1 \mathrm{~N}$ potassium dichromate and $20 \mathrm{ml}$ concentrated $\mathrm{H}_{2} \mathrm{SO}_{4}$ were added and the contents were shaken for a minute and then allowed to set aside exactly for 30 minutes and then $200 \mathrm{ml}$ distilled water, $10 \mathrm{ml}$ phosphoric acid and $1 \mathrm{ml}$ diphenylamine indicator were added. The solution was titrated against standard ferrous ammonium sulphate till color changes from blue violet to green. The blank titration was also carried without soil. Calcium carbonate content $\left(\mathrm{CaCO}_{3} \%\right)$ was determined volumetrically using calcimeter according to Horváth et al. (2005). The CEC was determined according to Sparks (1996). The active carbonate $\left(\mathrm{CaCO}_{3} \%\right.$ active) stirred the soil sample with a known amount of ammonium oxalate (N/5) filter. This solution is traced to permanganate before and after its contact with soil sample. The difference between the two titrations corresponds the amount of calcium of carbonate that reacted to oxalate of ammonium (Drouinea modified by Galet, 1951). Bases exchangeable: saturation by a solution of ammonium acetate $1 \mathrm{~N}$ adjusted to $\mathrm{pH}=7$. The content of total nitrogen was determined with a modified Kjeldahl's method (Bremner, 1960). The determination of cations has been performed by atomic absorption and flame photometer (Petard, 1993). Cationic exchange capacity (CEC): determined by the sodium acetate method (Petard, 1993). The typology is based essentially on a joint study of edaphic descriptors and individualized plant groups. This type of investigation has a particular interest in pastoral matters. It is the basis of development of model. In other words, this classification allows the manager to better understand the potential of the types of environment with a view to their rational use (pastoral management, reforestation, etc.). The basic data are constituted by a double-entry table or the variables that are arranged in columns and the statements in rows (Bounar, 2014).

\section{Results}

\section{Pedology data}

After three years of experimentation in the study area in two different seasons (cold and dry), the soil samples were examined (Table shows that the average of clay obtained is moderate and low for the three stations (A),(B) and (C). It ranges from 21 to $25 \%$; also, it is low for the third horizon of station (C) with $11 \%$. For silts, the average obtained is between 29 and $38 \%$ for the three stations and $21 \%$ for the third horizon of the station (C). The average obtained for the sands are moderate inside our experimental site and range from 30 to $36 \%$ for the three stations; however, the station (C), at the third horizon, has a reduced quantity of $29 \%$. The results for the percentage (\%) of clay in the three stations confirm the results discussed by Gaouar (2005) when he made his analysis of the typology soil of the nature reserve: El-Mergueb. Also, 
Pouget (1980) confirms that inside the degraded facies and/or more degraded the content of clay is low. This condition is due to soil degradation. The textures obtained explain the nature of the type of associated vegetation including the station (A), the steppe of Artemisia Herbaalba $\mathrm{L}$. is strongly related to areas where storm water or (rainwater) is more or less concentrated at station (B). Steppe of Salsola vermiculata L. and Anabasis articulata L. is strongly related to low-area texture on a crust and tangentially calcareous gypsum substrate. Station (C) that presents the steppe of Artemisia campestris L. and Zizyphus lotus L. occupies the texture characterized by the best lands constitute the richest paths with the presence of beds of alluvial oueds (Kaabeche, 2005) (Table 1). An examination of soil samples (Table 2) shows that the values for $\mathrm{pH}$ range from 8.4 to 8.61 , indicating that the soils are alkaline and under such conditions, the solubility of minerals decreases creating nutrient deficiencies in the soils according to CapotRey (1955). The content of organic matter (OM) value ranges from 0.43 to $1.37 \%$ except at station (C) with an average of $1.37 \%$. According to Pouget (1980) and Djebaili (1984), the average organic matter is 1 to $2 \%$ for steppe soils. The average of total limestone is between 19 and $24 \%$ in the three stations showing a calcareous character; according to Capot-Rey (1954) and Djili (2000), the average of the active carbonate is moderate, ranging from 13 to $19 \%$ for the

$\mathrm{T}$ a b le 1 . The averages obtained after particle size analysis in the laboratory.

\begin{tabular}{|l|c|c|c|c|}
\hline Samples of soils & Clay(\%) & Silt(\%) & Sand (\%) & Soil texture \\
\hline SAH1 E & 23 & 38 & 30 & Sandy clay loam \\
\hline SBH1 E & 22 & 34 & 33 & Sandy clay loam \\
\hline SCH1 E & 24 & 32 & 35 & Sandy loam \\
\hline SAH2 E & 25 & 29 & 32 & Sandy loam \\
\hline SBH2 E & 21 & 34 & 36 & Sandy loam \\
\hline SC H2 E & 19 & 30 & 34 & Sandy loam \\
\hline SCH3 E & 11 & 21 & 29 & Loamy sand \\
\hline
\end{tabular}

Notes: $S(A)$ - station A; S(B) - station B; S(C) - station C; E - three sampling campaigns; H- horizon of each depth.

T a b le 2. The average obtained after physicochemical analyses.

\begin{tabular}{|l|c|c|c|c|c|c|c|c|c|}
\hline Sample(s) & $\mathbf{p H} \mathbf{H}_{\mathbf{2}} \mathbf{O}$ & $\mathbf{p H ~ K C l}$ & $\begin{array}{c}\mathbf{C a C o}_{\mathbf{3}} \% \\
\text { total }\end{array}$ & $\begin{array}{c}\mathbf{C a C o}_{\mathbf{3}} \% \\
\text { active }\end{array}$ & $\mathbf{O M} \%$ & $\mathbf{C \%}$ & $\mathbf{N} \%$ & $\mathbf{C} / \mathbf{N}$ & $\mathbf{E C}(\mathbf{m S} / \mathbf{c m})$ \\
\hline SAH1 E & 8.49 & 7.55 & 23 & 18 & 0.98 & 0.57 & 0.6 & 0.95 & 0.98 \\
\hline SBH1 E & 8.47 & 7.82 & 21 & 14 & 0.43 & 0.25 & 0.83 & 0.31 & 1.65 \\
\hline SCH1 E & 8.43 & 7.8 & 20 & 18 & 1.37 & 0.8 & 1.04 & 0.76 & 1.45 \\
\hline SAH2 E & 8.42 & 7.81 & 22 & 15 & 0.86 & 0.5 & 0.35 & 1.42 & 1.38 \\
\hline SBH2 E & 8.4 & 7.78 & 23 & 17 & 0.94 & 0.55 & 0.52 & 1.05 & 1.21 \\
\hline SCH2 E & 8.41 & 7.56 & 19 & 13 & 0.77 & 0.45 & 0.97 & 0.46 & 1.20 \\
\hline SCH3 E & 8.61 & 7.66 & 24 & 19 & 0.86 & 0.5 & 0.9 & 0.55 & 0.91 \\
\hline
\end{tabular}

Notes: $\mathrm{pH} \mathrm{H}_{2} \mathrm{O}-\mathrm{pH}$ water; $\mathrm{pH} \mathrm{KCl}-\mathrm{pH}$ chloride of potassium; $\mathrm{CaCo}_{3} \%$ - total carbonate ; $\mathrm{CaCo}_{3} \%$ - active carbonate; OM\% - organic matter; $\mathrm{C} \%$ - total carbon; N\% - total nitrogen; $\mathrm{C} / \mathrm{N}$ - the carbon: nitrogen (C:N) ratio; EC - electric conductivity. 
T a b l e 3. The averages obtained after Cation Exchange Capacity Analysis [CEC (meq/100g)].

\begin{tabular}{|c|c|c|c|c|c|}
\hline Samples/ Site & $\mathrm{Na}+(\mathrm{meq} / \mathrm{100g})$ & $\mathrm{Mg}+(\mathrm{meq} / 100 \mathrm{~g})$ & $\mathrm{K}+(\mathrm{meq} / \mathbf{1 0 0 g})$ & $\mathrm{Ca}+(\mathrm{meq} / \mathbf{1 0 0 g})$ & $\mathrm{T}$ (meq/100g) \\
\hline SAH1E & 0.02 & 2.59 & 0.07 & 4.07 & 6.75 \\
\hline SBH1E & 0.02 & 4.17 & 0.06 & 4.92 & 9.17 \\
\hline SCH1E & 0.04 & 3.17 & 0.06 & 3.17 & 6.44 \\
\hline SAH2E & 0.01 & 1.84 & 0.04 & 3.25 & 5.14 \\
\hline SBH2E & 0.01 & 1.95 & 0.05 & 3.75 & 5.76 \\
\hline SC HE & 0.01 & 3,17 & 0.03 & 2.33 & 3.61 \\
\hline $\mathrm{SCH} 3 \mathrm{E}$ & 0.01 & 1.4 & 0.02 & 2.1 & 3.53 \\
\hline
\end{tabular}

Notes: $\mathrm{Na}+(\mathrm{meq} / 100 \mathrm{~g})$ - exchangeable sodium; $\mathrm{Mg}+(\mathrm{meq} / 100 \mathrm{~g})$ - exchangeable magnesium; K+ (meq/100g) exchangeable potassium; $\mathrm{Ca}+(\mathrm{meq} / 100 \mathrm{~g})$ - exchangeable calcium; $\mathrm{T}(\mathrm{meq} / 100 \mathrm{~g})$ - total of exchangeable cations.

three stations; according to Bonneau et al. (1979), if $\mathrm{pH}>7$, soils will be rich in active carbonate. Electrical Conductivity average value ranges from 0.91 to $1.65 \mathrm{mS} / \mathrm{cm}$ (Table 2). Electrical conductivity is used to estimate the soluble salt concentrations in soil and is commonly used as a measure of salinity. Soil with EC below $0.4 \mathrm{mS} / \mathrm{cm}$ are considered marginally saline or nonsaline, while soils above $0.8 \mathrm{mS} / \mathrm{cm}$ are considered severely saline. In the soils under analysis, the average were found to be non-saline, except for the second horizon of the station (A) and the second horizon of station (C) and first horizon of the station(B) having values $1.38-1.65$ and $1.45 \mathrm{mS} / \mathrm{cm}$ (Table 2). The measured electrical conductivity reveals unsalted soils for most of our stations except for the station's horizon of 02 . For the total carbon, average is fairly low for the three stations and the average of total nitrogen except for the station's horizon one $(\mathrm{C})$, the average of which is $1.04 \%$ which is moderate according to Djebaili (1984). The carbon/nitrogen ratio, which shows the fertility of the soil cover, is also low, with an average of all stations being $1 \%$ lower, except for two of the stations (A) and (B) being 1.05 and $1.42 \%$ considered moderate(classification of $\mathrm{C} / \mathrm{N}$ ratios in soils is defined in the UNDP project/FAO Gui72/004). The organic carbon (\%) ranges from 0.25 to $0.8 \%$, considered to be low in all three stations (Table 2). The average of exchangeable cation in all stations is between low to moderate The average of the two exchangeable Sodium and Potassium cations range $<0.5$, for the averages of the two exchangeable cations Magnesium and Calcium is between 2.1 to $4.92 \mathrm{meq} / 100 \mathrm{~g}$ and between 1.4 to $4.17 \mathrm{meq} / 100 \mathrm{~g}$, which prove the saturation of Calcium in the soils It is the case of the majority of degraded and overgrazing steppe soils in arid regions with herbaceous vegetation according to Pouget (1980) and Kaabeche $(1990,2005)$, where the capacity of exchange cations of our experimental site is less than $10 \mathrm{meq} / 100 \mathrm{~g}$. (Table 3), is an impermeable and of low-thickness substratum (Killian, 1961) (Table 3).

\section{Floristic data}

\section{Species richness}

The number of taxa counted in each station studied is 107 species and subspecies of 80 genera and 26 botanical families of vascular plants for the station (A) (Table 4). The station (B) 
contains a remarkable floristic diversity with 112 species belonging to 36 genera and 29 botanical families (Table 4) and station (C) includes a floristic list of 58 plant species distributed over 51 genera and 19 botanical families (Table 4). This number represents about 8\% of the total Algerian flora estimated at 3139 species (Quezel, Santa 1962, 1963). Of the total flora recorded at the park level, Asteraceae, Poaceae, Fabaceae, Liliaceae, Geraniaceae, Brassiceae, Plantaginaceae and Apiaceae are the most represented with a total of more than 5 species (Table 1). These families account for nearly $40 \%$ of the park's total species richness. Our results are consistent with those of Kaabeche (1990) and Djebaili (1984). These are wealthy places and the reserve are among the most diverse ecosystems in the country, having arid and semi-arid zones. This floristic richness places the reserve into a geographical position

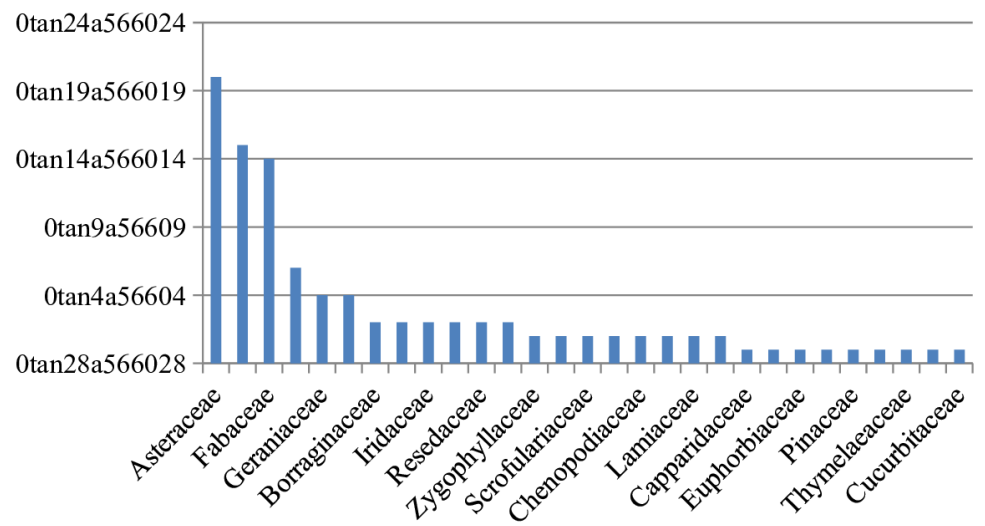

Fig. 4. Floristic diversity of station A.

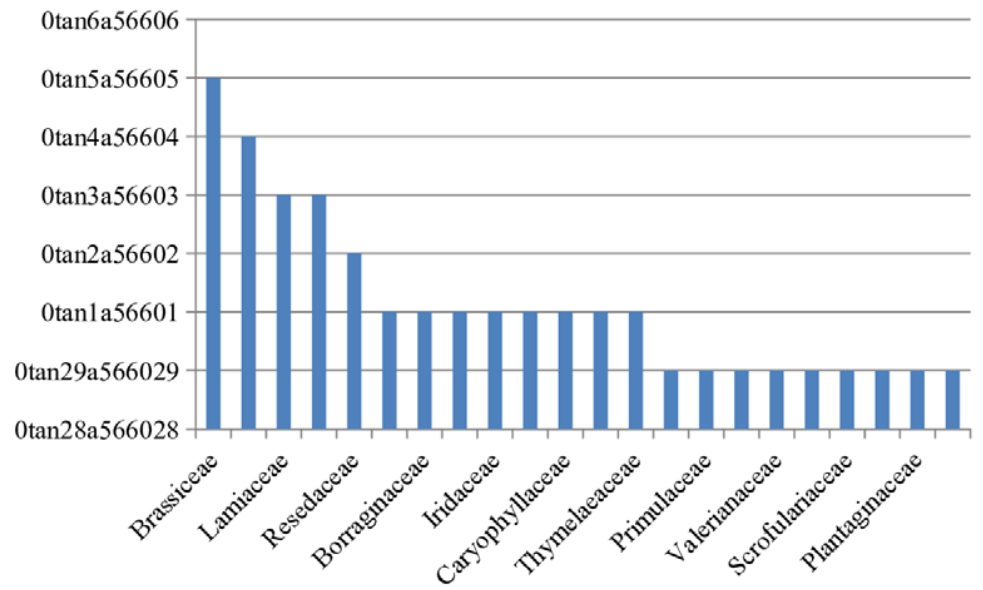

Fig. 5. Floristic diversity of the station B. 


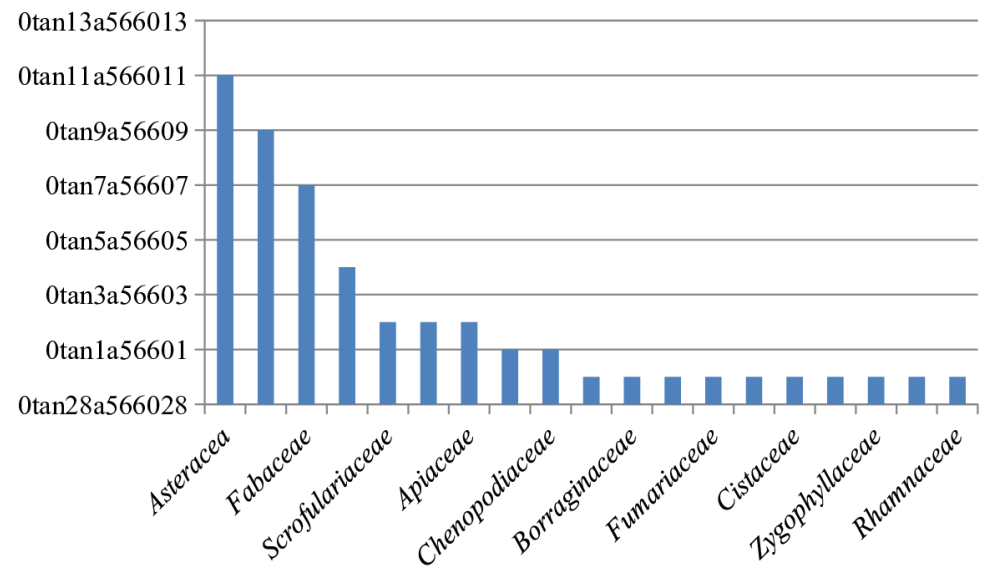

Fig. 6. Floristic diversity of station C.

that opens directly on the two atlases (Tellien and Saharan) and exposes it consequently to the North-South influences. The diversity of habitats, resulting from a climatic and edaphic heterogeneity and a relatively weak exploitation of the environment compared to other ecosystems, saw its legal status as a nature reserve.

Rare and endemic flora

At the level of endemic species, we counted (32) taxa, a rate of $11.55 \%$ compared to the total species of the El-Mergueb reserve and more than 3\% compared to the estimated total endemic flora of the country to 549 species (Quezel, 1964). This rate of endemism is relatively close to that recorded in several parks in central and eastern Algeria, such as (Belezma) Park Batna with 32 species, Gouraya (Bejaia) with 27 endemic taxa (Djurdjura) with 35 species (Meribai, 2006) and (Kala) Taref with 75 species (Stevenson et al., 1988). Alyssum scutigerum L., Anacyclus cyrtolepidioides L., Anvillea radiata L., Centaurea involuvrata L., Echium trygorrhizum L., Pomel linaria L., Laxiflora desf L., Scorzonera undulata Vahl. L., Stipa tenacissima L., Thymelaea microphylla L., Trigonella monspeliaca L., Xeranthemum inapertum L. The scarcity analysis, based on the data from (Quezel, Santa, 1962, 1963), identified nearly 24 species reported as rare or very rare. The EL-Mergueb reserve is one of the important sources to more than twenty Algerian taxa listed on the Red List of the International Union for the Conservation of Nature (IUCN, 1980).

Statistical analysis

Factor analysis is defined in the literature as a method of searching for interdependent relationships between several variables to define a given phenomenon, reducing the amount of information contained in the initial variables and establishing a smaller set of dimensions 
T a b l e 4. Number of families of different species studied.

\begin{tabular}{|l|c|c|c|c|}
\hline Family of plant & $\begin{array}{c}\text { Number of } \\
\text { endemic } \\
\text { species }\end{array}$ & $\begin{array}{c}\text { Proportion } \\
\text { (\%) }\end{array}$ & $\begin{array}{c}\text { Number of rare } \\
\text { species }\end{array}$ & $\begin{array}{c}\text { Proportion } \\
\text { (\%) }\end{array}$ \\
\hline Asteraceae & 09 & 28.12 & 07 & 29.16 \\
\hline Fabaceae & 04 & 12.5 & 02 & 8.33 \\
\hline Poaceae & 03 & 9.37 & 02 & 8.33 \\
\hline Brassicaceae & 03 & 9.37 & 02 & 8.33 \\
\hline Crassulaceae & 02 & 6.25 & 02 & 8.33 \\
\hline Resedaceae & 02 & 6.25 & 01 & 4.16 \\
\hline Lamiaceae & 02 & 6.25 & 01 & 4.17 \\
\hline Scrofulariaceae & 01 & 3.12 & 01 & 4.17 \\
\hline Apiaceae & 01 & 3.12 & 01 & 4.17 \\
\hline Liliaceae & 01 & 3.12 & 01 & 4.17 \\
\hline Chenopodiaceae & 01 & 3.12 & 01 & 4.17 \\
\hline Boraginaceae & 01 & 3.12 & 01 & 4.17 \\
\hline Thymelaeaeceae & 01 & 3.12 & 01 & 4.17 \\
\hline Rubiaceae & 01 & 3.12 & 01 & 4.17 \\
\hline Total & 32 & 99.95 & 24 & 100 \\
\hline
\end{tabular}

(called factors), aimed at minimizing the loss of information and analyzing the interdependence of the latter. The basic principle of factor analysis is to maximize the variance between the statistical units concerned and to find the central lines (components) of inertia (variation) of the point cloud (Gabor, 2010). To this end, our study uses a multivariate statistical analysis, CFA (Factorial Analysis Correspondence), which is a technical description of contingency tables and is primarily used to propose an analysis of a dataset of plant groups at each station that depended on edaphic variables. The typological results by CFA, highlighting the relationships between edaphic factors and vegetation, are illustrated in (Fig. 5). To better understand the interdependence of the parameters studied, the relationship between floristic records and their own edaphic factors is illustrated in Figures (Figs 5, 6). Floristic records, edaphic factors and plant species are represented by symbols accompanied by their codification.

The figure above shows the gradient of degradation of most groups of plants inside our experimental stations. Group B is the most ecologically stable by its floristic richness and edaphic parameters (Fig. 7); group $\mathrm{C}$ occupies the positive part with the edaphic environment. Moreover, the gradient of degradation inside the environment of the group A is noted to be situated the highest in the negative part, where the floristic richness is very low with a poor edaphic cover.

The spatial distribution of species is specified through a correspondence analysis (CA) performed on the stations species matrix (03 stations A, B and C taxa) (Fig. 8). The CA releases a system of factorial axes for making plane representations of all the columns and rows of the matrix. Each factor expresses some information about the analysis. The structures drawn by the clouds of variables are often significant and facilitate the demonstration of phenomena and ecological factors. The eigen values of axis 1 is 0.08 and of axis 2 is 0.075 , 


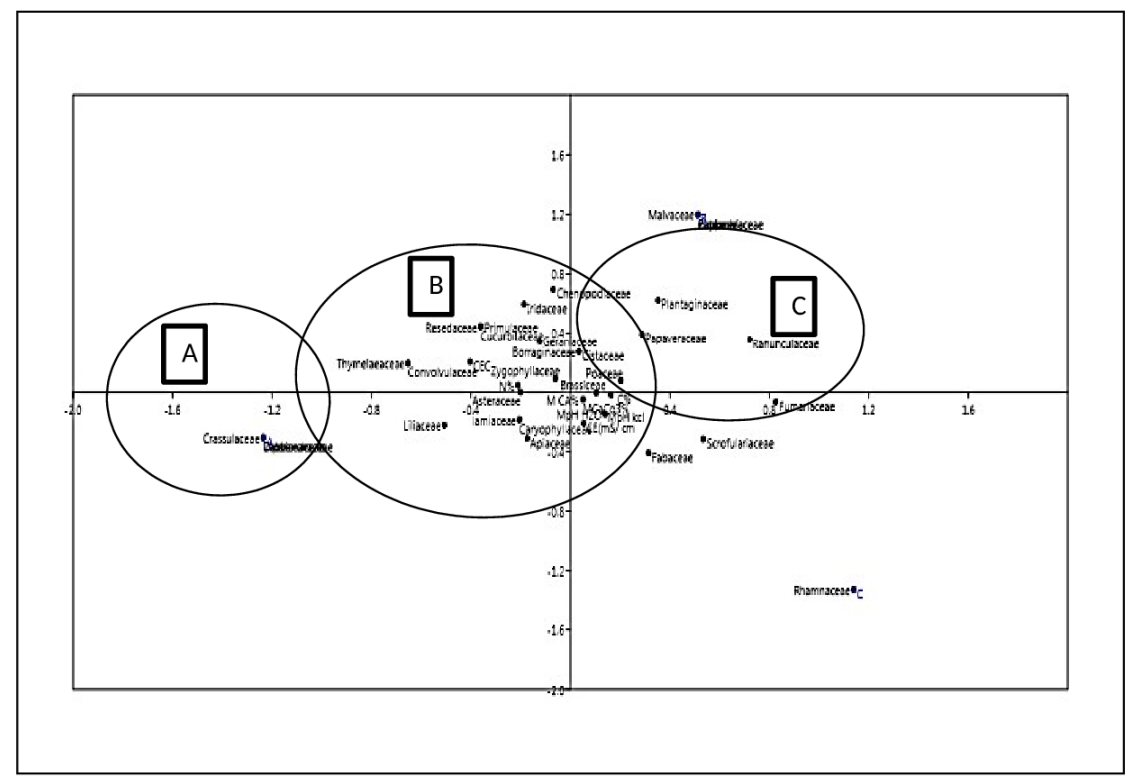

Fig. 7. Results of the factor analysis of the correspondence.

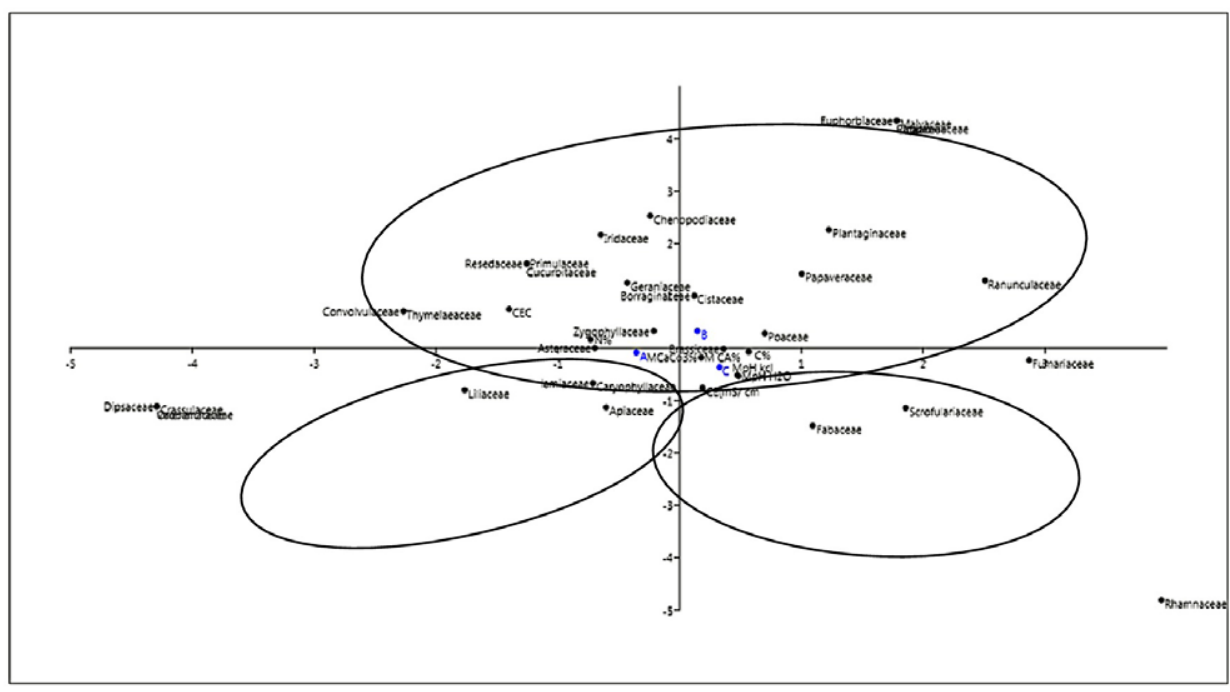

Fig. 8. Global analysis of vegetation data in relation to edaphic parameters. 
so the dependence between the rows and the columns is significant. In other words, there is a significant difference between stations, edaphic parameters and plant distribution. Figure 6 shows the distribution of plants and the edaphic parameters according to the stations. The inter-class inertia is expressed on axis F1 (52.19\%) and axis F2 (47.80\%); the information on the two main axes (Fig. 6) showed the spatial effect on the distribution of taxa. Axis 1 appears in two stations - station B and C - in positive position and in station A in negative position. Axis 2 in positive position finds station B (Table 5).

T a b l e 5. Signification of axes Inert and pure values.

\begin{tabular}{|l|c|c|c|}
\hline Axes & Eigenvalue & \% of total & Cumule \\
\hline 1 & 0.0827744 & 52.194 & 52.194 \\
\hline 2 & 0.0758142 & 47.806 & 100 \\
\hline
\end{tabular}

First group (Circle B): Corresponds to station (B) taxa and describes the taxa and edaphic parameters associated with this station Alyssum scutigerum L., Anacyclus cyrtolepidioides L., Anvillea radiata L., Centaurea involuvrata L., Echium trygorrhizum L. with: $\mathrm{pH}\left(\mathrm{H}_{2} \mathrm{O}\right)$ : 8.4-8.47; pHKcl : 7.78-7.82; $\mathrm{CaCo}_{3} \%: 21-23 \%$; $\mathrm{T}_{\mathrm{CEC}}$ (meq/100g) : 5.76-9.17 (Tables 2, 3). Second group (Circle C): Corresponds to the station (C) taxa and describes the taxa and edaphic parameters associated with this station Enarthrocarpus clavatus L., Muricaria prostrate L., Psychine stylosa L., Stipa tenacissima L., Thymus hirtus L. with $\mathrm{pH}\left(\mathrm{H}_{2} \mathrm{O}: 8.41-8.61\right.$; $\mathrm{pHKcl}: 7.56-7.8 ; \mathrm{CaCo}_{3} \%: 19-24 \% ; \mathrm{T}_{\mathrm{CEC}}$ (meq/100g) : 3.37-5.54) (Tables 2,3). Third group (Circle A): Corresponds to station A taxa to describe the taxa and soil parameters related to this station Linaria laxiflora L., Psychine stylosa L., Reichardia tingitana L., Reseda alba L., Salsola vermiculata L., Schismus barbatus subsp calycinus L., with $\mathrm{pH}\left(\mathrm{H}_{2} \mathrm{O}: 8.42-8.49\right.$; $\left.\mathrm{pHKcl}: 7.78-7.82 ; \mathrm{CaCo}_{3} \%: 22 \%-23 ; \mathrm{T}_{\mathrm{CEC}}(\mathrm{meq} / 100 \mathrm{~g}): 5.14-6.75\right)$ (Tables 2, 3).

\section{Discussion}

In general, it appears from these results after phyto-edaphic analysis that the contribution and the specific frequency of the developed stations are different from those of the undeveloped stations. The surface of the soil appears as a succession of dyes separated by very moderate bulges that dominate most of the experimental area (Boudjadja et al., 2010). Soils often encrusted are of small thickness. In some areas, the limestone crust that covers them is continuous and does not allow any plant rooting (Boudjadja et al., 2010). Gamoun et al. (2011) state that the sandy soil is more productive than the limestone soil in addition to creating hardness, limestone layers can reduce water penetration and reduce plant access to water. Janišová (2005) showed that the influence of dominant environmental factors is reflected sensitively in changes of vegetation composition. Therefore, differences in plant composition and proportion of species present in each family in all studied station are due to the differences in environmental factors. It should be noted, however, that both management and land use have a profound effect on vegetation. Assessment of the enclosure of some steppes area in 
northern Algeria by Boucherit et al. (2017) showed that grazing management could improve plant cover and diversity during the time. So in all studied stations, future management can improve vegetation conditions from cover and plant biodiversity. Because of the differentiation of altitude and micro-macro topography and climate, the vegetation ecosystems of the El-Mergueb region, there are distinguished different types of plant communities, and diverse species compositions and landscape complexes. Rahmonov et al. (2013) have also obtained similar results for the vegetation separation of lowland and mountainous areas in Tajikistan. The typology of soils acquired by the combined action of three factors: the climate, vegetation, and anthropogenic pressure, the partial pedological cover accentuates the impoverishment of his superficial horizons of soils. With these conditions, soils within our experimental area may be only poorly developed (Gaouar, 2005; Soil survey manual, 1937). As grazing animals trample and remove live vegetation and litter mass, production is reduced, especially in arid ecosystems (Gamoun et al., 2010). When production becomes low, leaves litter and organic carbon reduction are inevitable and this can affect soil properties. Greater organic matter can support more species, as seen on the station B. Moreover, the strong presence of different species of botanical families such as Asteraceae, Poaceae and Fabaceae indicate the strong grazing inside our study stations. According to Hirche et al. (2011), the main factor of degradation is overgrazing in arid and semi-arid region of Algeria and our study area is suffering from this phenomenon. So some resistance plant family like Asteraceae are present in the plant composition of station B and C in the first place. Previous studies established the same conclusion about the degradation of the steppe in Algeria (Hirche et al., 2011; Aidoud et al., 2006; Slimani et al., 2010) and Morocco (Benbrahim et al., 2004).

Our results proved the notion: The nature reserve of El-Mergueb is a unique steppe ecosystem and contains a specific biotope not existing throughout the Maghreb, which gives it an international dimension.

\section{Conclusion}

The study area is a region geographically located within a steppe ecosystem whose plant and soil diversity is remarkable, presenting a key indicator for this bioclimatic stage. Land degradation, anthropogenic pressure and climatic constraints have accentuated the decrease of the floristic richness and denuded the soil cover, of which this last wealth persists and resists. According to our interpretation, the presence of certain plant species has a climaterelated soil requirement whose adaptation is mandatory. The area is rich in endemic species but under pasture and climatic constraints, the vulnerability of species has become a major problem as per their numbers in each station. The low quantity of organic matter in the soils and other mineral elements under a total limestone level dominates majority of the study stations and along with decrease in rainfall, these form the major causes of disruption of growth and development of plants. Also, inside this type of ecosystem, plants can resist to develop with a minimum of climatic conditions and edaphic cover. The protected area of El-Mergueb characterized by a great vulnerability is where erosion dominates; it is accentuated by the negative action of arid climate. Our research proposes to protect the endemic species inside our site, which make the biodiversity inside this protected area unique, particularly in the 
homogeneous and heterogeneous facies to be representative of green space between two different climatic floors of the ecosystem.

\section{Acknowledgements}

I acknowledge assistant editor Eva Orbánová for her valuable contributions to this manuscript. I appreciate the criticism and suggestions that highly improved the quality of this manuscript provided by anonymous reviewers. I thank colleagues who offered crucial help in the field and the lab, at laboratory of Ecology and Environment (LREE), Abdurrahman Mira University of Bejaia, Algeria; International Desert Research Center (IDRC), University of Tehran, Iran; Department of Sciences of Nature and Life, Faculty of Sciences, Mohamed Boudiaf University of M'sila, Algeria; Institute of Ecology and Environmental Sciences (IEES) of Paris, France.

\section{References}

AFNOR (1998). French standard NF ISO 11259, X31-001, Soil quality. Simplified description of the soil. France.

Aïdoud, A., Le Floc'h, É. \& Le Houérou H.N. (2006). The arid steppe rangelands of Northern Africa. Science et Changements Planétaires/Sécheresse, 17(1), 19-30.

Aubert, H. \& Pinta M. (1978). Trace elements in soils. Soil Sci., 125(5), 334.

Baize, D. \& Jabiol B. (2011). Guide for soil description. Paris: INRA.

Benbrahim, K.F., Ismaili, M., Benbrahim, S.F. \& Tribak A. (2004). Problèmes de dégradation de l'environnement par la désertification et la déforestation: impact du phénomène au Maroc. Science et Changements Planétaires/ Sécheresse, 15(4), 307-320.

Bonneau, M.\&Souchier B. (Eds.) (1979). Pédologie 2.Constituants et propriétés du sol. Paris: Masson. DOI: 10.7202/1000421ar.

Boucherit, H., Benabdeli, K. \& Benaradj A. (2017). Biological recovery the steppe of Hammada scoparia after enclosure in the region of Naama (Algeria). Ekológia (Bratislava), 36(1), 52-59. DOI: 10.1515/eko-2017-0005.

Boudjadja, A., Kaddour, B.H. \& Pauc H. (2010). Increasing the value of surface water storage for protected wildlife, particularly the emblematic Cuvier's Gazelle, in Mergueb Reserve (M'sila, Algeria). Revue d'Ecologie - la Terree et la Vie, 65(3), 243-253. http://hdl.handle.net/2042/55842

Bounar, R. (2014). Etude des potentialités biologiques, cartographie et aménagement de la chaîne des Babors dans la démarche du développement durable. http://www.univ-setif.dz/Tdoctorat

Bremner, J.M. (1960). Determination of nitrogen in soil by the Kjeldahl method. J. Agric. Sci., 55, 11-33. DOI: $10.1017 /$ S0021859600021572.

Breuste, J., Schnellinger, J., Qureshi, S. \& Faggi A. (2013). Urban ecosystem services on the local level: urban green spaces as providers. Ekológia (Bratislava), 32(3), 290-304. DOI: 10.2478/eko-2013-0026.

Capot-Rey, R. (1955). Les sols d’Algérie d’après Mr J.H. Durand. Annales de Géographie, 64(341), 56-58. www.persee.fr/issue/geo_0003-4010_1955_num_64_341

Chapman, H.D. \& Pratt P.F. (1961). Methods of analysis for soils, plants and waters. Los Angeles: University of California.

Czudek, R. (2001). Some key issues in the context of the future of protected areas and wildlife management in Africa. Contribution to the forestry outlook study for Africa. Rome: Food and Agriculture Organization of the United Nations.

Djebaili, S. (1984). Steppes algériennes, phytosociologie et écologie. Alger: OPU.

Djili, K. (2000). Contribution à la connaissance des sols du Nord d'Algérie. Création d'une banque de données informatisées et utilisation d'un système d'information géographique pour la spatialisation et la valorisation des données pédologiques. Thèse d'état en sciences agronomiques. El- Harrach: INA.

Gabor, M.R. (2010).Descriptive methods of data analysis for marketing data - theoretical and practical considerations management \& marketing challenges for knowledge society. Management and Marketing, 5(3), 119-134. http://www.managementmarketing.ro/pdf/articole/198.pdf

Galet, M.P. (1951). Le dosage du calcaire actif et l'appréciation du pouvoir chlorosant des sols. Bull. d'Off. Inst. du Vin, 24, 37-42.

Gamoun, M., Tarhouni, M., Ouled Belgacem, A., Hanchi, B. \& Neffati M. (2010). Effects of grazing and trampling on primary production and soil surface in North African rangelands. Ekológia (Bratislava), 29(2), 219-226. DOI: 10.4149/ekol_2010_02_219. 
Gamoun, M. (2013). Vegetation change in variable rangeland environments: the relative contribution of drought and soil type in arid rangelands. Ekológia (Bratislava), 32(1), 148-157. DOI: 10.2478/eko-2013-0013.

Gaouar, A. (2005). Management plan of the site of El-Mergueb, hydrogeology, project DGF.NUD-ALG/G 35. In the national program of classification of the protected areas in Algeria.

Hilbert, D.W., Hughes, L., Johnson, J., Lough, J.M., Low, T., Pearson, R.G., Sutherst, R.W. \& Whittaker S. (2007). Biodiversity conservation research in a changing climate. Australia: CSIRO.

Hirche, A., Salamani, M., Abdellaoui, A., Benhouhou, S. \& Valderrama J.M. (2011). Landscape changes of desertification in arid areas: the case of south-west Algeria. Environ. Monit. Asses., 179(1-4), 403-420. DOI: 10.1007/ s10661-010-1744-5.

Horváth, B., Opara-Nadi, O. \& Beese F. (2005). A simple method for measuring the carbonate content of soils. Soil Sci. Soc. Am. J., 69, 1066-1068. DOI: 10.2136/sssaj2004.0010.

International Union for Conservation of Nature (IUCN) (1980). Lists of rare and endangered plants of the Mediterranean basin states. Athens: IUCN.

Jackson, M.L. (1962). Interlayering of expansible layer silicates in soils by chemical weathering. Clays and Clay Minerals, 11(1), 29-46. DOI: 10.1346/CCMN.1962.0110104.

Janišová, M. (2005). Vegetation-environment relationships in dry calcareous grassland. Ekológia (Bratislava), 24(1), 25-44.

Kaabeche, M. (1990). Vegetation groupings of the Boussada region (Algeria), synthesis test on the Maghreb steppe vegetation. PhD thesis, Ferhat Abess University of Setif, Algeria. www.univ-setif.dz/Tdoctorat/

Kaabeche, M. (2003). Conservation de la Biodiversité et gestion durable des ressources naturelles: étude sur la réhabilitation de la flore locale au niveau de la réserve «El-Mergueb» (Wilaya de M'sila, Algerie). Algerie: Ministere de L'Agriculture et du Developpement Rural Direction Generale des Forets.

Kaabeche, M. (2005). Management plan of the site of El-Mergueb, hydrogeology, project DGF.NUD-ALG/G 35. In the national program of classification of the protected areas in Algeria.

Killian, L. (1961). Natural and artificial improvement of a pasture in an Algerian Reserve "Le Mergueb". Northern Africa.

Le Houérou, H.N. (2005a). Atlas of climatic diagrams for the isoclimatic Mediterranean regions. Montpellier: Copymania.

Le Houérou, H.N. (2005b). The isoclimatic mediterranean biomes. Bioclimatology, diversity and phytogeography. Montpellier: Copymania.

Leadley, P., Pereira, H.M., Alkemade, R., Fernandez-Manjarrés, J.F., Proença, V., Scharlemann, J.P.W. \& Walpole M.J. (2010). Biodiversity scenarios: projections of 21st century change in biodiversity and associated ecosystem services. Montreal: Secretariat of the Convention on Biological Diversity.

Maire, R. (1926). Phytogeographical map of Algeria and Tunisia. Gouverneur General Algérie

Maire, R. (1928). Origin from the flora of the mountains of Northern Africa. Memo. Soc. Biogéogr, 2, 187-194.

Maire, R. (1952). Flora of North Africa (Morocco, Algeria, Tunisia, Tripolitania, Cyrenaica and the Sahara). Vol. 16. Paris: Lechevalier.

Maire, R. (1952,1987). Flora of North Africa (Morocco, Algeria, Tunisia, Tripolitania, Cyrenaica and Sahara). Vol. 1 to 16. Paris: Lechevalier.

Merdas, S., Menad, A., Mostephaoui, T. \& Sakaa B. (2017). Plant community structure and diversity under grazing gradient in arid Mediterranean steppe of Algeria. Journal of Materials and Environmental Sciences, 8, 4329-4338. DOI : 10.26872/jmes.2017.8.12.456.

Meribai, Y. (2006). Study of vegetation in Djurjura National Park phytosociology and proposal development. Magister thesis, Ecology: Phytosociology. Algeria: National Institute of Agronomy.

Pendleton, R.L. \& Nickerson D. (1951). Soil colors and special Munsell soil color charts. Soil Sci., 71(1), 35-44.

Petard, J. (1993). The analyses methods. Vol. 1. Soils analyses. Paris: Orstom.

Pouget, M. (1980). Les relations sol-végétation dans les steppes Sud-Algéroises. Paris: Orstom. http://www.documentation.ird.fr/hor/fdi:00344

Quezel, P. \& Santa S. (1962). New flora of Algeria and southerly desert regions. Paris: CNRS.

Quezel, P. \& Santa S. (1963). Nouvelle flore de l. Algérie et des régions désertiques méridionales. CNRS: Paris.

Quezel, P. (1964). L'endémisme dans la flore d’Algérie. Compte Rendu Sommaire des Séances de la Société de Biogéographie, 361, 137-149.

Rahmonov, O., Majgier, L., Andrejczuk, W., Banaszek, J., Karkosz, D., Parusel, T. \& Szymczyk A. (2013). Landscape diversity and biodiversity of Fann Mountains (Tajikistan). Ekológia (Bratislava), 32(4), 388-395. DOI: 10.2478/ eko-2013-0037. 
Robinson, G.W. (1922). A new method for the mechanical analysis of soil and other dispersions. J. Agric. Sci., 12, 306-321. DOI: 1017/S0021859600005360.

Slimani, H., Aidoud, A. \& Roze F. (2010). 30 Years of protection and monitoring of a steppic rangeland undergoing desertification. J. Arid Environ., 74(6), 685-691. DOI : 10.1016/j.jaridenv.2009.10.015.

Soil survey manual (1937). Bureau of plant industry soils, and agriculture engineering. Washington: United State Department of Agriculture.

Sparks, D.L. (1996). Methods of soil analysis. Part 3: Chemical methods. Madison: Soil Science Society of America, American Society of Agronomy.

Stephen, M.P. (2015). The impact of ecosystem services knowledge on decisions. Partial Fulfillment of the Requirements for the Degree of Doctor of Philosophy Specializing in Natural Resources.

Stevenson, A.C., Skinner, J., Hollis, G.E. \& Smart M. (1988). The El Kala National Park and Environs, Algeria: An Ecological Evaluation. Environ. Conserv., 15, 335-348. DOI: 10.1017/S0376892900029830.

Tandon, H.L.S. (1993). Methods of analysis of soils, plants, waters, and fertilizers. New Delhi: Fertiliser Development and Consultation Organisation.

United Nations Framework Convention on Climate Change (UNFCCC) (2007). Climate change in developing countries: impacts, vulnerabilities and adaptation.

Walkley, A. (1947).An critical examination of a rapid method for determining organic carbon in soils. Effect of variations in digestion conditions and of inorganic soil constituents. Soil Sci., (63), 251-264.

Wetang'ula, G.N. (2009). Biodiversity, conservation and loss: international legal mechanism for management. In Short Course IV on Exploration for Geothermal Resources, organized by UNU-GTP, Ken Gen and GDC (pp. 1-8). Lake Naivasha, Kenya, November 1-22, 2009. 